\title{
Prevalence and Risk Factors of Helicobacter Pylori Recurrence in Egyptian Patients with Liver Cirrhosis
}

\author{
Mohamed G. Hamed, Mohamed A.A. Bassiony, Ayman F. Elsayed Mohamed \\ Internal Medicine Department, Faculty of Medicine, Zagazig University,Egypt \\ Corresponding Author: Mohamed Bassiony, Mobile: 00201205664331 , E-mail: dr_mbh13303@yahoo.com
}

\begin{abstract}
Background: Helicobacter pylori (H. pylori) is a worldwide gastrointestinal infection. It is a common risk factor for peptic ulcer disease (PUD), chronic gastritis, and stomach cancer. In patients with cirrhosis, there is a significant association between $\mathrm{H}$. pylori infection and severity of gastropathy due to portal hypertension, chronic stomach upset, frequent upper gastrointestinal bleeding as well as hepatic encephalopathy.

Objective: To assess the rate and risk factors of recurrence of $\mathrm{H}$. pylori infection in Egyptian patients with liver cirrhosis after successful eradication therapy. Patients and methods: This study included 500 liver cirrhosis patients who were tested for H. pylori infection. Patients with positive H. pylori infection received proton pump inhibitors (PPI)-based treatment regimen. Successful eradication therapy was assessed 4-8 weeks and repeated over one year after end of treatment using urea breath test (UBT) and stool antigen test (SAT).
\end{abstract}

Results: The prevalence of $\mathrm{H}$. pylori infection in cirrhotic patients was 58\%. There were significantly higher serum levels of ammonia and C-reactive protein (CRP) in H. pylori positive patients as well as significantly more gastritis in endoscopy findings in comparison with $\mathrm{H}$. pylori-negative patients. H. pylori recurrence after successful eradication therapy was observed in $22.1 \%$ patients of $\mathrm{H}$. pylori-positive cirrhotic patients. Multivariate analysis showed that higher serum ammonia level \& receiving multiple treatment courses to achieve $\mathrm{H}$. pylori eradication were independent risk factors for $\mathrm{H}$. pylori recurrence in cirrhotic patients.

Conclusion: H. pylori infection is prevalent in liver cirrhosis patients with a significant recurrence rate after eradication therapy. High serum ammonia and the need for multiple treatment courses are risk factors for recurrence.

Keywords: Helicobacter pylori, Liver cirrhosis, Eradication therapy, Hepatitis C, Ammonia level, Bacterial resistance.

\section{INTRODUCTION}

H. pylori is a gram-negative, microaerophilic, highly-motile and spiral-shaped bacterium infecting more than $50 \%$ of the world population through oro-oral or feco-oral transmission ${ }^{(\mathbf{1})}$. H. pylori infection is the most prevalent risk factor for chronic gastritis, peptic ulcer disease (PUD), gastric carcinoma (which is the second leading cause of cancer-related death worldwide), and mucosal associated lymphoid tissue (MALT) lymphoma. H. pylori is also a probable risk factor for multiple extra-gastric disorders, such as ischemic heart disease, diabetes, iron \& vitamin B12 deficiency and idiopathic thrombocytopenic purpura as well as some liver disorders including nonalcoholic fatty liver disease, isolated hypertransaminasemia, and portosystemic encephalopathy ${ }^{(2,3)}$.

$\mathrm{H}$. pylori recurrence is negative detection of $\mathrm{H}$. pylori at 4 weeks after eradication therapy but positive detection at a later time. Despite the awareness of the risks of $\mathrm{H}$. pylori infection \& the multiple regimens offered for its eradication, there is still a high risk of $\mathrm{H}$. pylori recurrence after successful eradication therapy with one-year recurrence rate $1-2 \%$ in developed countries but $10-70 \%$ in developing countries. H. pylori recurrence can occur either by reconolization of the same H. pylori strain (recrudescence) or a new strain (reinfection) with most cases of $\mathrm{H}$. pylori recurrence are due to recrudescence. Many risk factors for H. pylori infection have been reported, including socioeconomic factors, education level, non-compliance to treatment, bacterial resistance \& prolonged alcohol intake ${ }^{(4)}$.

Cirrhosis caused by chronic hepatitis $\mathrm{C}$ virus infection and its complications is one of the major health

problems in Egypt. H. pylori infection is a common cause of PUD in cirrhotic patients, and it is also correlated with the severity of portal hypertensive gastropathy (PHG) and frequent upper gastrointestinal bleeding in those patients. However, there are insufficient data in the literature on the rate and risk factors for recurrence of $\mathrm{H}$. pylori infection after successful resection treatment in cirrhotic patients ${ }^{(5)}$.

The aim of our study was to assess the rate and risk factors of recurrence of $\mathrm{H}$. pylori infection in Egyptian patients with liver cirrhosis after successful eradication therapy.

\section{PATIENTS AND METHODS}

This prospective study was carried on in Gastroenterology and Hepatology Unit, Internal Medicine Department, Zagazig University Hospitals from January 2020 till March 2021. Inclusion criteria: included age $>18$ years, both sexes, and evidence of liver cirrhosis. Exclusion criteria: included pregnant or lactating females, patients with gastric cancer, and history of $\mathrm{H}$. pylori treatment 4 weeks ago or after one year of end of therapy. The study enrolled 500 liver cirrhosis patients who were tested for $\mathrm{H}$. pylori infection. In accordance with American College of 
Gastroenterology (ACG) guidelines 2017, the patients with positive $\mathrm{H}$. pylori infection received proton pump inhibitors (PPI)-based treatment regimen [PPI+ Amoxicillin + Clarithromycin (PAC), PPI+ Amoxicillin + Levofloxacin (PAL) or PPI+ Clarithromycin + Levofloxacin (PCL)] for $\mathrm{H}$. pylori eradication. The confirmation of successful eradication therapy or $\mathrm{H}$. pylori recurrence was done 4-8 weeks after end of treatment course using urea breath test (UBT) and stool antigen test (SAT) ${ }^{(6)}$. Follow up UBT and SAT were performed for patients without recurrence at $3,6 \& 12$ months.

\section{Ethical approval:}

An approval of the study was obtained from Zagazig University academic and ethical committee. All

\section{RESULTS}

Table (1): Demographic data of the study groups.

\begin{tabular}{|c|c|c|c|}
\hline Variables & $\begin{array}{c}\text { H. pylori-negative } \\
N .=210(42 \%)\end{array}$ & $\begin{array}{c}\text { H. pylori-positive } \\
\text { N. }=290(58 \%)\end{array}$ & P-value \\
\hline Age (years) & $53.4 \pm 7.6$ & $52.7 \pm 8.6$ & 0.35 \\
\hline $\operatorname{Sex}(M / F)$ & $131 / 79$ & $183 / 107$ & 0.78 \\
\hline BMI $\left(\mathrm{Kg} / \mathrm{m}^{2}\right)$ & $27.8 \pm 2.3$ & $28.1 \pm 2.8$ & 0.2 \\
\hline Smoking (\%) & $76(36.2)$ & $101(34.8)$ & 0.75 \\
\hline Alcohol intake (\%) & $3(1.43)$ & $8(2.76)$ & 0.32 \\
\hline $\begin{array}{l}\text { Education level }(\%) \\
\text { Low } \\
\text { Medium } \\
\text { High }\end{array}$ & $\begin{array}{l}79(37.6) \\
65(31) \\
66(31.4)\end{array}$ & $\begin{array}{l}118(40.7) \\
89(30.7) \\
83(28.6)\end{array}$ & $\begin{array}{l}0.48 \\
0.94 \\
0.49\end{array}$ \\
\hline $\begin{array}{l}\text { Socio-economic status (Income) (\%) } \\
\geq 2000 \text { EGP } \\
<2000 \text { EGP }\end{array}$ & $\begin{array}{l}131(62.4) \\
79(37.6)\end{array}$ & $\begin{array}{l}187(64.5) \\
103(35.5)\end{array}$ & 0.63 \\
\hline Diabetes mellitus (\%) & $72(34.3)$ & $98(33.8)$ & 0.91 \\
\hline Hypertension (\%) & $21(10)$ & $33(11.4)$ & 0.62 \\
\hline $\begin{array}{l}\text { Causes of cirrhosis }(\%) \\
\text { HCV } \\
\text { HBV }\end{array}$ & $\begin{array}{c}206(98.1) \\
4(1.9)\end{array}$ & $\begin{array}{c}287(98.3) \\
5(1.7)\end{array}$ & 0.87 \\
\hline Hemoglobin (g/dl) & $9.6 \pm 0.8$ & $9.5 \pm 1.1$ & 0.26 \\
\hline WBCs $\left(\times 10^{3} / \mathrm{dl}\right)$ & $3.4 \pm 0.5$ & $3.3 \pm 0.8$ & 0.51 \\
\hline Platelet count $\left(\times 10^{3} / \mathrm{dl}\right)$ & $96.1 \pm 9.2$ & $97.4 \pm 4.1$ & 0.52 \\
\hline ALT (IU/L) & $46 \pm 10.2$ & $46.2 \pm 10.1$ & 0.83 \\
\hline AST (IU/L) & $45.3 \pm 2.1$ & $45.7 \pm 2.6$ & 0.72 \\
\hline Serum albumin (g/dl) & $2.9 \pm 0.7$ & $2.85 \pm 0.1$ & 0.56 \\
\hline Total Bilirubin (mg/dl) & $1.5 \pm 0.06$ & $1.6 \pm 0.07$ & 0.07 \\
\hline Prothrombin time (sec.) & $1.54 \pm 0.03$ & $1.56 \pm 0.02$ & 0.37 \\
\hline Serum creatinine (mg/dl) & $1.09 \pm 0.2$ & $1.1 \pm 0.2$ & 0.58 \\
\hline Serum ammonia $(\mu \mathrm{mol} / \mathrm{l})$ & $103 \pm 8.2$ & $115 \pm 9.4$ & $<0.001 *$ \\
\hline CRP (ng/ml) & $2.4 \pm 0.2$ & $2.5 \pm 0.1$ & $<0.001 *$ \\
\hline Child-Pugh score & $8.9 \pm 2.2$ & $8.8 \pm 2.4$ & 0.74 \\
\hline MELD score & $15.8 \pm 3.9$ & $16.2 \pm 2.9$ & 0.19 \\
\hline $\begin{array}{l}\text { Endoscopic findings (\%) } \\
\text { Esophageal varices } \\
\text { Gastric varices } \\
\text { PHG } \\
\text { Gastritis } \\
\text { PUD } \\
\end{array}$ & $\begin{array}{c}97(46.2) \\
41(19.5) \\
71(33.8) \\
144(69) \\
51(24.3)\end{array}$ & $\begin{array}{c}129(44.5) \\
62(21.4) \\
117(40.3) \\
222(77) \\
81(27.9)\end{array}$ & $\begin{array}{c}0.71 \\
0.6 \\
0.14 \\
\mathbf{0 . 0 4} * \\
0.37 \\
\end{array}$ \\
\hline
\end{tabular}

This study evaluated 500 liver cirrhosis patients for H. pylori infection. Table (1) showed that 290 cirrhotic patients $(58 \%)$ tested positive for $\mathrm{H}$. pylori infection, $63 \%$ were males and their mean age was 53 years. There were no statistically significant differences between $\mathrm{H}$. pylori-positive \& H. pylori-negative cirrhotic patients regarding age, sex, alcohol intake, socio-economic status, education level, underlying cause of liver cirrhosis, Child score, model for endstage liver disease (MELD) score, esophageal \& gastric varices, PHG or PUD. There were significantly higher serum 
levels of ammonia and C-reactive protein (CRP) in H. pylori positive patients as well as significantly more gastritis in endoscopy findings in comparison with $\mathrm{H}$. pylori-negative patients.

Table (2): Univariate analysis of risk factors for $\mathrm{H}$. pylori recurrence.

\begin{tabular}{|c|c|c|c|}
\hline & $\begin{array}{l}\text { Cirrhotic } \\
\text { patient } \\
\text { with } \mathrm{H} . \\
\text { pylori } \\
\text { recurrence } \\
\text { (N.=64) }\end{array}$ & $\begin{array}{c}\text { Cirrhotic } \\
\text { patients } \\
\text { without } H . \\
\text { pylori } \\
\text { recurrence } \\
\text { (N.= 226) }\end{array}$ & $\begin{array}{r}P- \\
\text { value }\end{array}$ \\
\hline Age (years) & $51.9 \pm 4.1$ & $52.3 \pm 5.2$ & 0.57 \\
\hline $\begin{array}{l}\text { Alcohol intake } \\
(\%)\end{array}$ & $3(4.7)$ & $5(2.2)$ & 0.28 \\
\hline $\begin{array}{l}\text { Socio- } \\
\text { economic } \\
\text { status }(\%) \\
>2000 \text { EGP } \\
<2000 \text { EGP }\end{array}$ & $\begin{array}{cc}40 & (62.5) \\
24 & (37.5)\end{array}$ & $\begin{array}{l}138(61.1) \\
88 \quad(38.9)\end{array}$ & 0.84 \\
\hline $\begin{array}{l}\text { Education level } \\
(\%) \\
\text { Low } \\
\text { High } \\
\end{array}$ & $\begin{array}{l}27(42.2) \\
20(31.3)\end{array}$ & $\begin{array}{l}91(40.3) \\
63(27.9)\end{array}$ & $\begin{array}{l}0.79 \\
0.59\end{array}$ \\
\hline $\begin{array}{l}\text { Hemoglobin } \\
\text { level (gm/dl) }\end{array}$ & $9.1 \pm 1.2$ & $9.2 \pm 1.3$ & 0.58 \\
\hline $\begin{array}{l}\text { Prothrombin } \\
\text { time (sec.) }\end{array}$ & $1.4 \pm 0.03$ & $1.3 \pm 0.05$ & 0.13 \\
\hline $\begin{array}{l}\text { High serum } \\
\text { ammonia level } \\
\text { (umol/l) }\end{array}$ & $114 \pm 5.4$ & $111 \pm 9.7$ & 0.02* \\
\hline MELD score & $15.1 \pm 3.2$ & $14.8 \pm 3.5$ & 0.54 \\
\hline $\begin{array}{l}\text { CRP level } \\
\text { (ng/ml) }\end{array}$ & $2.1 \pm 0.2$ & $2.1 \pm 0.4$ & 1 \\
\hline PHG (\%) & $22(34.4)$ & $95(42)$ & 0.27 \\
\hline PUD (\%) & 17 (26.6) & $64(28.3)$ & 0.79 \\
\hline
\end{tabular}

Table (2) showed that $\mathrm{H}$. pylori recurrence after successful eradication therapy was observed in 64 (22.1\%) patients of $\mathrm{H}$. pylori-positive cirrhotic patients. Univariate analysis for risk factors showed that the only probable risk factor for $\mathrm{H}$. Pylori recurrence after successful eradication therapy was higher serum ammonia level in cirrhotic patients with $\mathrm{H}$. pylori recurrence. There was no statistically significant difference between cirrhotic patients with $\mathrm{H}$. pylori recurrence and those without $\mathrm{H}$. pylori recurrence regarding age, alcohol intake, socio-economic status, education level, MELD score and presence of PUD or PHG.

Table (3): Correlation between H. Pylori recurrence \& severity of liver cirrhosis.

\begin{tabular}{|l|c|c|c|}
\hline & $\begin{array}{c}\text { Patients } \\
\text { with } \\
\text { H. pylori }\end{array}$ & $\begin{array}{c}\text { Patients } \\
\text { without } \\
\text { H. pylori }\end{array}$ & Palue \\
& recurrence \\
(N. =64) & recurrence & \\
(N. =226) & \\
\hline
\end{tabular}

\begin{tabular}{|l|c|c|c|}
\hline $\begin{array}{l}\text { Compensated } \\
\text { liver cirrhosis } \\
\text { (Child score < 7) }\end{array}$ & $18(28 \%)$ & $72(32 \%)$ & \multirow{2}{*}{0.54} \\
\cline { 1 - 3 } $\begin{array}{l}\text { Decompensated } \\
\text { liver cirrhosis } \\
\text { (Child score } \geq 7)\end{array}$ & $46(72 \%)$ & $154(68 \%)$ & \\
\hline
\end{tabular}

Table (3) showed no statistically significant difference between compensated $\&$ decompensated liver cirrhosis patients regarding $\mathrm{H}$. pylori recurrence.

Table (4): Multivariate analysis of the study group.

\begin{tabular}{|l|c|c|c|}
\hline \multicolumn{1}{|c|}{ Variant } & $\begin{array}{c}\text { Odd } \\
\text { ratio }\end{array}$ & $\begin{array}{c}\mathbf{9 5 \%} \\
\text { CI }\end{array}$ & P-value \\
\hline Alcohol intake & 1.5 & $0.9-3.1$ & 0.53 \\
\hline $\begin{array}{l}\text { High Serum } \\
\text { ammonia level }\end{array}$ & 4.2 & $1.2-$ & $\mathbf{0 . 0 2} *$ \\
\hline $\begin{array}{l}\text { Receiving multiple } \\
\text { treatment courses }\end{array}$ & 3.4 & 14.8 & $1.2-$ \\
\hline PHG & 2.7 & $0.7-3$ & $\mathbf{0 . 0 3} *$ \\
\hline
\end{tabular}

Multivariate analysis revealed that higher serum ammonia level \& receiving multiple treatment courses to achieve $\mathrm{H}$. pylori eradication were independent risk factors for H. pylori recurrence in cirrhotic patients after successful eradication therapy as shown in table (4).

\section{DISCUSSION}

The prevalence of $\mathrm{H}$. pylori infection in developing countries ranges from $70-90 \%$ with a recurrence rate ranging from $10-70 \%$ after successful eradication treatment. This high prevalence in developing countries is thought to be due to lower socioeconomic conditions, contaminated food and water, higher cost of eradication treatment and higher non-compliance with treatment ${ }^{(7)}$.

In cirrhotic patients, $H$. pylori infection is implicated in an increased prevalence of upper gastrointestinal bleeding due to more severe PUD and PHG as well as an increased prevalence and severity of systemic portal encephalopathy mainly due to increased ammonia production ${ }^{(8)}$.

In our study, we assessed the prevalence and risk factors of $\mathrm{H}$. pylori recurrence in cirrhotic patients after successful eradication therapy. Our results showed that the prevalence of $\mathrm{H}$. pylori infection in patients with liver cirrhosis was 58\%. This finding goes in agreement with Pogorzelska et al. ${ }^{(9)}$ who reported H. pylori infection in $61 \%$ of patients with liver cirrhosis secondary to HCV infection, while it was $29 \%$ in those with alcoholic cirrhosis.

H. pylori-positive cirrhotic patients were mainly males (63\%), with a mean age 53 years, and had statistically significant higher serum ammonia levels, serum CRP levels and more gastritis rates in their endoscopic findings. These findings are consistent with those reported by Abdel-Razik et al. ${ }^{(\mathbf{1 0})}$ and Leontiadis et al. ${ }^{(11)}$. 
Abdul Sathar et al. ${ }^{(12)}$ reported a strong association between $\mathrm{H}$. pylori infection \& PHG where H. pylori infection was present in $44 \%$ versus $27 \%$ of liver cirrhosis patients without versus with PHG respectively. This association wasn't present in our findings.

Our results revealed that $22 \%$ of $\mathrm{H}$. pyloripositive patients showed recurrence after successful eradication therapy. These findings are similar to that recurrence rate reported by Hong et al. ${ }^{(13)}$ and Andreev et al. (14) (18\% and 20-26\% respectively). This recurrence was not correlated with age, sex, alcohol intake, socio-economic status, education level or complication of $\mathrm{H}$. pylori infection (PUD). Also, $\mathrm{H}$. pylori recurrence wasn't correlated with the severity of liver disease according to Child \& MELD scores or with presence of PHG.

We found that the independent risk factors associated with $\mathrm{H}$. pylori recurrence in cirrhotic patients after successful eradication therapy were higher serum ammonia level and receiving multiple PPI-based treatment courses to achieve $\mathrm{H}$. pylori eradication. Elevated serum ammonia levels in patients with recurrent $\mathrm{H}$. pylori infection may indicate further gastric and diffuse colonic interference with $\mathrm{H}$. pylori. This is mainly due to the effect of $\mathrm{H}$. pylori urease on protein digestion in the colon. Increased production of ammonia by $\mathrm{H}$. pylori bacteria in cirrhotic patients is implicated in recurrent hepatic encephalopathy in these patients ${ }^{(\mathbf{1 5})}$. Increased $\mathrm{H}$. pylori recurrence in patients receiving multiple treatment courses may be a clue for more resistance to antibiotic therapy in our group of patients. This is consistent with the findings of Silva et al. (16) who reported that recurrence rates of $\mathrm{H}$. Pylori infection is increased with history of previous treatments. This also goes in agreement with Sachdeva et $\boldsymbol{a l} .{ }^{(17)}$ who reported that eradication rates are decreasing over time with increase in antibiotic resistance.

\section{CONCLUSION}

H. pylori infection is prevalent in liver cirrhosis patients with a significant recurrence rate after eradication therapy. High serum ammonia \& the need for multiple treatment courses are risk factors for recurrence.

\section{REFERENCES}

1. Kipritci Z, Gurol Y, Celik G (2020): Antibiotic Resistance Results of Helicobacter pylori in a University Hospital: Comparison of the Hybridization Test and Real-Time Polymerase Chain. Int J Microbiol., 2020: 8853298.

2. Sugano K, Tack J, Kuipers E et al. (2015): Kyoto global consensus report on Helicobacter pylori gastritis. Gut, 64 (9): 1353-67.

3. Hooi J, Lai W, Khoon W et al. (2017): Global Prevalence of Helicobacter pylori Infection: Systematic
Review and Meta-Analysis. Gastroenterol., 153 (2): 420-29.

4. Fernandes Y, Bonatto G, Bonatto M (2016): Recurrence rate of helicobacter pylori in patients with peptic ulcer five years or more after successful eradication. Arq Gastroenterol., 53 (3): 152-5.

5. Shen-Shong C, Hsiao-Yun H (2015): Helicobacter pylori: Effect of coexisting diseases and update on treatment regimens. World J Gastrointest Pharmacol Ther., 6 (4): 127-36.

6. Chey W, Leontiadis G, Howden C et al. (2017): ACG Clinical Guideline: Treatment of Helicobacter pylori Infection. Am J Gastroenterol., 112 (2): 212-239.

7. Ierardi E, Giorgio F, Losurdo G et al. (2013): How antibiotic resistances could change Helicobacter pylori treatment: A matter of geography? World J Gastroenterol., 19 (45): 8168-80.

8. Cheng-En T, Chih-Ming L, Chen-Hsiang $\mathrm{L}$ et al. (2016): First-line Helicobacter pylori eradication among patients with chronic liver diseases in Taiwan. KJMS., 32 (8): 397- 02.

9. Pogorzelska J, Lapińska M, Kalinowska A et al. (2017): Helicobacter pylori infection among patients with liver cirrhosis. Eur J Gastroenterol Hepatol., 29 (10): 1161-65.

10. Abdel-Razik A, Mousa N, Elhelaly $R$ et al. (2020): Helicobacter pylori as an initiating factor of complications in patients with cirrhosis: A single-center observational study. Front., 7: 96-103.

11. Leontiadis G, Sharma V, Howden C (1999): NonGastrointestinal Tract Associations of Helicobacter pylori Infection. What Is the Evidence? Arch Intern Med., 159 (9): 925-40.

12. Abdul Sathar S, Kunnathuparambil S, Sreesh S et al. (2014): Helicobacter pylori infection in patients with liver cirrhosis: prevalence and association with portal hypertensive gastropathy. Ann Gastroenterol., 27 (1): 48-52.

13. Hong L, Zhao Y, Han Y et al. (2007): Reversal of migraine symptoms by Helicobacter pylori eradication therapy in patients with hepatitis-B-related liver cirrhosis. Helicobacter, 12 (4): 306-8.

14. Andreev N, Maev V, Kucheryavyi A et al. (2016): The efficiency and safety of anti-Helicobacter pylori therapy in patients with concomitant chronic hepatitis C. Therap Archiv., 88 (4): 75-81.

15. Ito S, Miyaji H, Azuma $T$ et al. (1995): Hyperammonemia and Helicobacter pylori. Lancet, 346(8967):124-5.

16. Silva F, Zaterka S, Eisig J et al. (2001): Factors affecting Helicobacter pylori eradication using a sevenday triple therapy with a proton pump inhibitor, Tinidazole and Clarithromycin in Brazilian patients with peptic ulcer. Rev Hosp Clinc Fac Med S. Paulo., 56 (1): 11-16.

Sachdeva A, Rawat S, Nagpal J (2014): Efficacy of fermented milk and whey proteins in Helicobacter pylori eradication: A review. World J Gastroenterol., 20 (3): 724-37. 